\title{
Screening of phytochemical and pharmacological activities of Syzygium caryophyllatum (L.) Alston
}

Stalin N and Sudhakar Swamy $P^{*}$

\begin{abstract}
Background: The systematic screening of plant species with the purpose of discovering new bioactive compounds is prerequisite for any bioprospecting study. Therefore the present study was carried out to assess the phytochemical content and the evaluation of in vitro antioxidant, antibacterial, larvicidal and antidiabetic activities of the methanol extracts of S.caryophyllatum bark, leaves, fruit pulp and seeds.
\end{abstract}

Methods: The quantitative estimation of total phenol, flavonoid and tannin content of the extracts of S. caryophyllatum bark, leaf, fruit pulp and seeds were analyzed by using standard methods. The present study also conducted to screen antioxidant (DPPH, ABTS assays), antimicrobial, antidiabetic (in vitro a-amylase and a-glucosidase inhibitory assays) and larvicidal (against fourth instars larvae of Aedes aegypti and Culex quinquefasciatus) activities of methanol extract of $S$. caryophyllatum.

Results: The results of quantitative phytochemical analysis revealed the presence of maximum amount of phytoconstituents such as phenol, flavonoids and tannins in the leaf, bark and seed extract when compared to fruit pulp extracts. Free radical scavenging activity indicated that methanol bark, leaves, fruit and seeds extracts has significant free radical scavenging ability on DPPH with percentage inhibition of $88.15 \%, 81.31 \%, 75.24 \%$ and $83.36 \%$ respectively. The in vitro a-amylase and a-glucosidase inhibitory studies of the methanol crude extracts of four different plant parts of S. caryophyllatum (Bark, leaf fruit pulp and seed) showed good inhibitory activities in concentration dependent manner. The maximum percentage inhibitory activity of $78.03 \%$ was showed at concentration of $500 \mu \mathrm{g} / \mathrm{ml}$ seed extracts followed by bark (78.03\%), leaf (69.4\%) and fruit pulp (56.9\%) at the same concentration. While the percentage inhibitory activity of four extracts also showed potent inhibition of a-glucosidase; maximum inhibition exhibited at the concentration of $100 \mu \mathrm{g} / \mathrm{ml}$ by bark extract (80.9\%) compared with other extracts, leaf (78.2\%), seed (77.59\%) and fruit pulp (63.35\%). The leaf essential oil and four extracts showed significant mortality against fourth instars larvae of Ae. aegypti and CX. quinquefasciatus respectively.

Conclusion: Thus the present study suggests that S.caryophyllatum plant parts can be used as natural antioxidant source to prevent diseases associated with free radicals. Also, this plant can be a good source for further purification studies for isolation and characterization of compounds related to these antioxidants, antidiabetic and antibacterial activities.

Keywords: Syzygium caryophyllatum, DPPH, ABTS, Larvicidal, Free radicals

\footnotetext{
* Correspondence: swamypsplantscience@gmail.com

Department of Plant Science, School of Biological Sciences, Madurai Kamaraj University, Madurai, Tamil Nadu -21, India
} 


\section{Background}

Nature has been a resource of medicinal treatments for thousands of years, and plant derived products being continued to play a crucial role in primary health care of approximately $80 \%$ of the world's population [1]. Plant based drugs can be derived from any part of the plant like leaves, bark, flowers, fruits, root etc. i.e., any part of the plant may contain active components. The systematic screening of plant species with the purpose of discovering new bioactive compounds is prerequisite for any bioprospecting study. The fruits from wild edible plants possess significant amount of vitamins ( $\beta$-carotene, vitamins $C$ and $E$ ), flavonoids and other polyphenolic compounds having high free-radical scavenging activity [2]. An epidemiological study provides convincing evidence of the beneficial role of fruits and vegetables in the diet for the maintenance of health and prevention of diseases [3]. Polyphenols represent a diverse class of compounds including flavonoids (i.e. flavones, flavonols, flavanones, flavononols, flavan-3-ols and chalcones), tannins and phenolic acids [4]. These polyphenols are products of secondary metabolism in plants, and their important role of chelating transitional metals and scavenging free radicals activity are mainly due to their redox properties and chemical structures [5]. Antioxidants are vital substances which possess the ability to protect the body from tissue damage caused by free radical induced oxidative stress [6]. In addition to common antioxidants like vitamin $\mathrm{C}$, vitamin $\mathrm{E}$ and carotenoids, phenolic constituents such as flavonoids, tannins and anthocyanins present in food of plant origin are also potential antioxidants [7-9].

Plant phenolics present in the fruit and vegetables have received considerable attention because of their potent antioxidant property. Plants possess more phenolic content show better antioxidant activity this is due to the direct correlation between total phenolic content and antioxidant activity [10, 11]. Natural products of higher plants may possess a new source of antimicrobial agents with possibly novel mechanism of action $[12,13]$. They are effective in the treatment of infectious diseases while simultaneously mitigating many of the side effects that are often associated with synthetic antimicrobials [14].

Mosquitoes are the most important single group of insects in terms of public health importance, which are responsible for spreading a number of severe diseases, such as malaria, filariasis, dengue, Japanese encephalitis, etc. Culex quinquefasciatus is a major contributor for transmitting vector borne diseases like fevers and filariasis to human beings and animals. More than 40 million peoples affected globally from Elephantiasis and are badly debilitated and disfigured from this disease [15]. Aedes mosquitoes on the other hand are vectors of important viral diseases of man such as the zika virus, dengue and yellow fevers. Ae. aegypti is reported to be the principal vector of dengue fever in tropical countries, a disease considered a serious public health problem world over, especially in areas where the environmental conditions for the development of Aedes mosquitoes abound. Totally, 2.35 million people suffering from dengue was reported in America alone (as per 2013 data) of which 7687 cases were rigorous [16]. According to Directorate of National Vector Borne Disease Control Programme (NVBDCP), till July 30, 2016, the total dengue cases in India were 16,870 while for the same period in 2017 they numbered 28,702. Recently, the infections have been raised due to an increased urbanization, trade, and travel. No effective drug or vaccine is available so far. Frequent uses of these synthetic insecticides create an increase resistance among the mosquitoes and to cause adverse impacts on nontarget organisms or humans. With this scenario, biological control especially plant based insecticide has proven as better in controlling insect vectors.

Plant extracts have long been used for the treatment of diabetes in various traditional systems of medicine and are now accepted as an alternative for diabetic treatment. Type II diabetes mellitus is a chronic endocrine metabolic disorder that affects the carbohydrates, proteins and fat metabolism. Postprandial increase of blood glucose is the major problem in diabetic patients. Inhibitors of $\alpha$-amylase and $\alpha$-glucosidase enzymes delay the breaking down of carbohydrates in the small intestine and decrease the postprandial blood glucose levels. Inhibitors of $\alpha$-amylase and $\alpha$-glucosidase isolated from medicinal plants to serve as an alternative drug with increased potency and lesser adverse effects than existing synthetic drugs.

Syzygium caryophyllatum (L.) Alston., an endangered evergreen tree belongs to the family Myrtaceae, commonly known as Wild black plum. This tree is native to Sri Lanka and India; in India the distribution is restricted to the forests of Western Ghats regions. S. caryophyllatum fruits are edible, sweet and astringent in taste. The seeds and bark were dried and its decoction was used in the ailment of diabetes mellitus [17]. The leaf and bark extracts of this plant are well known for its antibacterial and antioxidant efficacy [18]. Root extract using different solvent system exhibited promising amount of phenol, flavonoids, tannins and vitamin C [19]. The bark extract of this plant was used in veterinary medicine for the treatment of tympanitis in cattles [20]. Tribal people consider this plant as a boon of nature and its fruits and seeds were consumed by Paniya tribal community of Waynad district, Kerala, India [21]. As the plant is used for medicinal purposes, the investigation of chemical constituents in the plant parts 
and its biological activities may provide valuable information. There is a detailed bioprospecting studies by using different organic solvent system with different plant parts have not been studied previously on S. caryophyllatum. Therefore the present study was carried out (i) to analyse the leaves essential oil and its antibacterial and larvicidal activities (ii) to assess the total phenols, flavonoids and tannins content; (iii) to evaluate the in vitro antioxidant, antibacterial, larvicidal and antidiabetic activities of the methanol extracts of S.caryophyllatum bark, leaves, fruit pulp and seeds.

\section{Methods}

\section{Plant material and sample preparations}

S. caryophyllatum plant samples (Leaves, bark and fruits) were collected from Kannur district of Kerala, India during 2012 and voucher specimen (PLS2011007) was prepared, identified and deposited at the Department of Plant Science herbarium, Madurai Kamaraj University. The bark, leaves, fruit pulp and seeds were separately dried at below $40{ }^{\circ} \mathrm{C}$. Powdered sample of S.caryophyllatum bark, leaves, fruit pulp and seeds was sequentially extracted with hexane, ethyl acetate, methanol and water in their increasing polarity by sonicator. The extracts were filtered through Whatman No.1 filter paper and the solvents were evaporated under reduced pressure. Dried extracts obtained were stored in $4{ }^{\circ} \mathrm{C}$ until further analysis.

\section{Estimation of total phenol content}

The amount of total phenol in plant extracts was determined with the Folin-Ciocalteu reagent using the method given by Lister and Wilson [22]. $100 \mu \mathrm{l}$ of appropriate dilutions of extracts were dissolved in $500 \mu \mathrm{l}$ (1/10 dilution) of the Folin-Ciocalteu reagent and $1000 \mu \mathrm{l}$ of distilled water. The solutions were mixed and incubated at room temperature for $1 \mathrm{~min}$. After $1 \mathrm{~min}, 1500 \mu \mathrm{l}$ of $20 \%$ sodium carbonate $\left(\mathrm{Na}_{2} \mathrm{CO}_{3}\right)$ solution was added to the mixture and then incubated for $2 \mathrm{~h}$ in the dark at room temperature. A standard curve was prepared by using gallic acid as a standard. Different concentrations of gallic acid were prepared in $80 \%$ of methanol. The absorbances of all samples were measured at $760 \mathrm{~nm}$ using a UVVis spectrophotometer (Model. U.2800, Hitachi) and the total phenol contents were expressed as $\mathrm{mg} / \mathrm{g}$ gallic acid equivalent (GAE) using the equation obtained from the calibration curve using the following eqs.

$$
Y=b \times+c
$$

Where, Y-absorbance of extract; c-intercept; b-slope of the calibration curve; $\mathrm{x}$ - concentration of extract.

$$
\begin{aligned}
& X=Y-c / m \\
& C=c V / m
\end{aligned}
$$

Where, C-Total phenolic content; c-concentration of gallic acid obtained from calibration curve in $\mathrm{mg} / \mathrm{ml}$; Vvolume of extract in $\mathrm{ml} ; \mathrm{m}$ - mass of extract in gram.

\section{Estimation of total flavonoid content}

Estimation of total flavonoid content in the dried extracts was determined spectrophotometrically following the method given by Quettier-Deleu et al. [23]. This method is based on the formation of a complex flavonoid-aluminium, having the absorbtivity maximum at $430 \mathrm{~nm} .1 \mathrm{ml}$ of diluted sample was separately mixed with $1 \mathrm{ml}$ of aluminum chloride solution $(2 \% w / v)$. After incubation at room temperature for $15 \mathrm{~min}$, the absorbance of the reaction mixture was measured at $430 \mathrm{~nm}$. Rutin was used to make the calibration curve. The flavonoid content was expressed in $\mathrm{mg}$ per $\mathrm{g}$ of rutin equivalent (RE using the equation obtained from the calibration curve using the following eqs.

$$
Y=b x+c
$$

Where, Y-absorbance of extract; c-intercept; b-slope of the calibration curve; $\mathrm{x}$ - concentration of extract.

$$
X=Y-c / m
$$

$$
C=c V / m
$$

Where, C-Total flavonoid content; c-concentration of rutin obtained from calibration curve in $\mathrm{mg} / \mathrm{ml}$; Vvolume of extract in $\mathrm{ml} ; \mathrm{m}$ - mass of extract in gram.

\section{Estimation of tannin content}

The amount of tannin content was determined by modified Prussian blue method [24]. This method is based on the mechanism that the phenols reduce potassium ferricyanide to produce ferrous ions; these ferrous ions in turn react with ferric chloride in the presence of dilute $\mathrm{HCl}$ to form a Prussian blue coloured complex, which can be measured spectrophotometrically at $700 \mathrm{~nm}$ wavelength. $100 \mu \mathrm{l}$ of appropriate dilutions of extracts were dissolved in distilled water to make up the volume of $7 \mathrm{ml}$. The sample solution was mixed with $1 \mathrm{ml} \mathrm{po-}$ tassium ferricyanide followed by the addition of $1 \mathrm{ml}$ ferric chloride. The absorbance of samples was measured at $700 \mathrm{~nm}$. Tannic acid was used to make a calibration curve. The amount of tannin in plant extracts was calculated by using the equation obtained from the calibration curve using the following eqs. 


$$
Y=\mathrm{bx}+\mathrm{c}
$$

Where, Y-absorbance of extract; c-intercept; b-slope of the calibration curve; $\mathrm{x}$ - concentration of extract.

$$
X=Y-c / m
$$

$$
C=c V / m
$$

Where, C-Total Tannin content; c-concentration of Tannic acid obtained from calibration curve in $\mathrm{mg} / \mathrm{ml}$; $\mathrm{V}$-volume of extract in $\mathrm{ml}$; $\mathrm{m}$ - mass of extract in gram.

\section{In vitro free radical scavenging assays}

\section{Free-radical scavenging ability (DPPH-assay)}

The scavenging ability of leaf essential oil, bark, leaves, fruit pulp and seed extracts on DPPH free- radicals was estimated according to the method of Shimada et al. (1992) [25]. This method depends on the reduction of purple 1,1-diphenyl-2-picrylhydrazyl (DPPH) to a yellow coloured diphenyl picrylhydrazine and the remaining DPPH which showed maximum absorption at $517 \mathrm{~nm}$ was measured. About $2 \mathrm{ml}$ of various concentrations of test samples and ascorbic acid and gallic acid standards $(2.5-20 \mu \mathrm{g} / \mathrm{ml})$ were mixed with $0.5 \mathrm{~mL}$ of $1 \mathrm{mM} \mathrm{DPPH}$ in methanol. An equal amount of methanol and DPPH served as control. The mixture was shaken vigorously and then incubated for $30 \mathrm{~min}$ at room temperature in dark. The absorbance of the samples/standards was measured at $517 \mathrm{~nm}$ against the blank. The decrease of the absorbance of the DPPH solution indicates an increase in $\mathrm{DPPH}$ radical scavenging activity. The experiment was performed in triplicates. The DPPH radical scavenging activity was calculated according to the following equation:

$$
\begin{aligned}
& \% \mathrm{DPPH} \text { radical scavenging activity } \\
& =(\text { Ao-A } 1) / \text { Ao } \times 100 \%
\end{aligned}
$$

where Ao is the absorbance of the control reaction and A1 is the absorbance in the presence of the sample of the tested extracts. Percentage radical activity was plotted against the corresponding antioxidant substance concentration to obtain the $\mathrm{IC}_{50}$ value, which is defined as the amount of antioxidant substance required to scavenge the $50 \%$ of free radicals present in the assay system. $\mathrm{IC}_{50}$ values are inversely proportional to the antioxidant potential.

\section{ABTS radical cation scavenging assay}

ABTS radical cation scavenging assay was carried out by the method of Re et al. [26]. 2,2' -azino-bis(3-ethylbenzothiazoline-6-sulphonic acid) $\left(\mathrm{ABTS}^{2 \bullet}\right)$ radical cation was generated by adding $14 \mathrm{mM}$ ABTS to $4.9 \mathrm{mM}$ ammonium persulphate and the mixture was allowed to stand for $12-16 \mathrm{~h}$ in the dark at room temperature. This solution was diluted to obtain an absorbance of $0.7 \pm$ 0.05 with ethanol at $734 \mathrm{~nm}$ (Shimadzu UV-Vis spectrophotometer model 2450) and the same was used for further assay. To 900ul of ABTS radical solution, added 100ul of the different concentrations of extracts (100$1000 \mu \mathrm{g} / \mathrm{ml}$ ) and ascorbic acid and gallic acid standards (2.0-10 $\mu \mathrm{g} / \mathrm{ml})$. The solution was shaken well and the absorbance was measured after $7 \mathrm{~min}$. The capacity to scavenge the ABTS radical cation was calculated using the formula same as DPPH method.

\section{In vitro antidiabetic assays a-amylase inhibition assay}

The $\alpha$-amylase inhibitory activity of the methanol extracts of bark, leaves, fruit pulp and seed of the S.caryophyllatum was determined according to the method described by Ranilla et al. [27]. A total of $250 \mu \mathrm{L}$ of sample/standard and $125 \mu \mathrm{L}$ of $0.02 \mathrm{M}$ sodium phosphate buffer ( $\mathrm{pH} 6.9$ with $6 \mathrm{mM} \mathrm{NaCl}$ ) containing $\alpha$ - amylase solution $(0.5 \mathrm{mg} / \mathrm{mL})$ was incubated at $25{ }^{\circ} \mathrm{C}$ for $10 \mathrm{~min}$. After pre-incubation, $250 \mu \mathrm{L}$ of $1 \%$ starch solution in $0.02 \mathrm{M}$ sodium phosphate buffer ( $\mathrm{pH} 6.9$ with $6 \mathrm{mM}$ $\mathrm{NaCl}$ ) was added to each tube at timed intervals. The reaction mixtures were then incubated at $25{ }^{\circ} \mathrm{C}$ for $10 \mathrm{~min}$. The reaction was stopped with $0.5 \mathrm{~mL}$ of dinitrosalicylic acid colour reagent. The test tube was then incubated in a boiling water bath for $5 \mathrm{~min}$ and cooled to room temperature. The reaction mixture was then diluted after adding $5 \mathrm{~mL}$ of distilled water and absorbance was measured at $540 \mathrm{~nm}$. Acarbose was used as the positive control. The $\alpha$-amylase inhibitory activity was calculated as follows;

$\%$ Inhibition of $\alpha$-amylase $=(A o-A 1) / A o \times 100 \%$.

Where, Ao is the absorbance of the control reaction and $A 1$ is the absorbance in the presence of the sample of the tested extracts.

\section{a-glucosidase inhibition assay}

The $\alpha$-glucosidase inhibitory activity was assessed by Dong et al. [28] with slight modifications. Briefly, a volume of $60 \mu \mathrm{L}$ of sample/acarbose standard solution and $50 \mu \mathrm{L}$ of $0.1 \mathrm{M}$ phosphate buffer ( $\mathrm{pH}$ 6.8) containing $\alpha$ glucosidase solution $(0.2 \mathrm{U} / \mathrm{mL})$ was incubated in 96 well plates at $37{ }^{\circ} \mathrm{C}$ for $20 \mathrm{~min}$. After pre-incubation, $50 \mu \mathrm{l}$ of $5 \mathrm{mM} p$-nitrophenyl- $\alpha$-D-glucopyranoside (PNPG) solution in $0.1 \mathrm{M}$ phosphate buffer ( $\mathrm{pH}$ 6.8) was added to each well and incubated at $37{ }^{\circ} \mathrm{C}$ for another $20 \mathrm{~min}$. Then the reaction was stopped by adding $160 \mu \mathrm{L}$ of $0.2 \mathrm{M} \mathrm{Na}_{2} \mathrm{CO}_{3}$ into each well, and absorbance 
was recorded at $405 \mathrm{~nm}$ by micro-plate reader and compared to a control which had $60 \mu \mathrm{L}$ of buffer solution in place of the extract. The $\alpha$-glucosidase inhibitory activity was expressed as percentage inhibition and was calculated same as $\alpha$-amylase.

\section{Antibacterial sensitivity tests}

Antibacterial activity of bark, leaves, fruit pulp and seed extracts were investigated by the disc diffusion method [29]. Antibacterial activity was carried out against six bacteria viz., Bacillus cereus, B. licheniformis, Escherichia coli, Staphylococcus aureus, S. hominis and Aerococcus viridians. Mueller-Hinton agar medium (MHA) was used for antibacterial susceptibility tests. Petri plates were prepared by pouring $20 \mathrm{~mL}$ of MHA medium and allowed to solidify. The bacterial suspensions were then streaked over the media surface using a sterile cotton swab to ensure confluent growth of the organism. $20 \mu \mathrm{L}$ of $2.5 \mathrm{mg} / \mathrm{mLof}$ bark, leaves, fruit pulp and seed extracts were impregnated on sterile discs of $6 \mathrm{~mm}$ size. The discs were then aseptically placed on the surface of agar plates at well-spaced intervals. The plates were incubated at $37^{\circ} \mathrm{C}$ for $24 \mathrm{~h}$ and the observed zones of inhibition were measured. DMSO serve as a control and antibiotic discs $(6.0 \mathrm{~mm}$ in diameter) of $10 / 10 \mu \mathrm{g} / \mathrm{mL}$ Ampicillin/Sulbactum, $120 \mu \mathrm{g} / \mathrm{mL}$ Gentamycin were also used as positive controls. Antibacterial activity was evaluated by measuring the diameter of the zone of inhibition against tested bacteria.

The minimum inhibitory concentration (MIC) values were determined for the bacterial strains which were sensitive to the bark, leaves, fruit pulp and seed extracts in disc diffusion assay. The inoculums of the bacterial strains were prepared from $12 \mathrm{~h}$ broth cultures and suspensions were adjusted to $0.5 \mathrm{McF}$ arland standard turbidity. The bark, leaves, fruit pulp and seed extracts of $S$. caryophyllatum dissolved in 5\% dimethyl sulfoxide (DMSO) were first diluted to the highest concentration $(1000 \mu \mathrm{g} / \mathrm{mL})$ to be tested, and then serial twofold dilutions were made in order to obtain a concentration range from $62.5-1000 \mu \mathrm{g} / \mathrm{mL}$ in $10 \mathrm{~mL}$ sterile test tubes containing nutrient broth. MIC values of S. caryophyllatum bark, leaves, fruit pulp and seed extracts against bacterial strains were determined based on a microwell dilution method. The tubes were observed after incubation of $24 \mathrm{~h}$ at $37^{\circ} \mathrm{C}$. After incubation, the MIC of each sample was determined by visual inspection of the tubes. The lowest concentration of the active ingredient that inhibited growth, as detected by a lack of visual turbidity was taken to be the MIC.

\section{Larvicidal activity}

The larvicidal activity of the leaf essential oil and methanol extracts of bark, leaf, fruit pulp and seed of $S$. caryophyllatum were tested according to the WHO [30] procedure with slight modifications. Larvicidal activity was tested against two mosquito vectors namely Aedes aegypti (Ae. aegypti) and Culex quinquefasciatus (Cx. quinquefasciatus). The larvae were obtained from Centre for Research in Medical Entomology, Madurai. The essential oil was dissolved in methanol to make the stock solution of $10,000 \mathrm{ppm}(10 \mu \mathrm{L} / 1 \mathrm{~mL})$. From the stock solution, concentration of 10,50,100, 200 and $400 \mathrm{ppm}$ were prepared. The $1 \%$ stock solution of crude extracts of bark, leaf, fruit pulp and seed were prepared with methanol. From the stock solution, $500-62.5 \mathrm{mg} / \mathrm{L}$, dilutions were prepared with methanol. Twenty early fourth instars larvae were introduced in insects breeding box containing $100 \mathrm{~mL}$ of water with each concentration. A control was prepared by the addition of methanol. Larvae were fed a diet of dry yeast and dog biscuits. The numbers of dead larvae were counted after $24 \mathrm{~h}$ of exposure and the percentage mortality was reported from the average of three replicates. The average larval mortality data were subjected to probit analysis for calculating $\mathrm{LD}_{50}$ and $\mathrm{LD}_{90}$ values were calculated by using the software BioStat, 2009.

Percent mortality $=\%$ Mortality in treated
$-\%$ Mortality in control $/ 100-\%$ Mortality in Control

\section{Statistical analysis}

All data were reported as mean \pm standard deviation/ standard errors of means of three replicates. The $\mathrm{IC}_{50}$ values were calculated using the ED50plus $\mathrm{v} 1.0$ programme. Statistical analyses were performed using Microsoft Excel.

\section{Results}

The quantitative estimation of total phenol, flavonoid and tannin contents of different solvent extracts of $S$. caryophyllatum bark, leaf, fruit pulp and seed were analysed. The concentration of total phenol content expressed in terms of gallic acid equivalent (GAE) (the standard curve equation: $y=0.188 x+0.030, R^{2}=$ 0.997). The concentrations of total phenol content in bark, leaf, fruit pulp and seed extracts of S. caryophyllatum ranged from 0.74 to $36.1 \mathrm{mg}$ GAE/g dry weight. The highest amount of total phenol was found to be in methanol extracts of leaf $(36.1 \mathrm{mg}$ GAE /g), bark (31.6 mg GAE /g) and seed (29.1 mg GAE /g). While ethyl acetate extracts of leaf, bark and seed were also exhibited significant amount of phenol content with 25.7, 17.8 and $22.28 \mathrm{mg}$ GAE/g respectively. The lowest concentration of total phenol content was obtained in fruit pulp extracts (Table 1). 
Table 1 The quantitative estimation of total phenol content of the different solvent extracts of S. caryophyllatum leaf, bark fruit pulp and seed

\begin{tabular}{lllll}
\hline $\begin{array}{l}\text { Phytoconstituents } \\
\text { (mg/g dry weight) }\end{array}$ & Leaf & Bark & Fruit pulp & Seed \\
\hline Hexane & $3.95 \pm 0.2$ & $8.4 \pm 0.4$ & $0.74 \pm 0.1$ & $5.47 \pm 0.14$ \\
Ethyl Acetate & $25.7 \pm 0.1$ & $17.8 \pm 0.2$ & $6.27 \pm 0.15$ & $22.28 \pm 0.1$ \\
Methanol & $36.1 \pm 0.9$ & $31.6 \pm 0.2$ & $8.61 \pm 0.2$ & $29.1 \pm 0.3$ \\
Water & $6.98 \pm 0.2$ & $21.8 \pm 0.1$ & $2.65 \pm 0.1$ & $15.5 \pm 0.2$ \\
\hline
\end{tabular}

Values are given as mean \pm SD of triplicate experiment

The concentration of total flavonoid content was expressed in terms of (RE) rutin equivalent (the standard curve equation: $\left.y=0.175 \times-0.029, R^{2}=0.994\right)$. The concentration of flavonoid content in bark, leaf, fruit pulp and seed extracts of $S$. caryophyllatum ranged from 0.51 to $5.63 \mathrm{mg} \mathrm{RE} / \mathrm{g}$ dry weight. The highest concentration of flavonoid level was obtained in methanol extract from the leaf (5.63 $\mathrm{mg} \mathrm{RE} / \mathrm{g}$ ) followed by bark methanol (3.6 mg RE/g) and leaf water extract (3.75 mg RE/g) respectively. Fruit pulp and seed extracts of all solvent fractions showed significant amount of flavonoid content. The lowest concentration of flavonoid was found in hexane and ethyl acetate extracts of leaves and bark (Table 2).

Total tannin content in bark, leaf, fruit pulp and seed extracts were expressed in terms of (TAE) tannic acid equivalent (the standard curve equation: $y=0.229 x+$ $\left.0.041 \mathrm{R}^{2}=0.998\right)$. The maximum concentration of total tannin content was found to be $36.6 \mathrm{mg} \mathrm{TAE} / \mathrm{g}$ in methanol extract of leaf followed by methanol bark extract (31.3 mg TAE/g), water leaf extract (26.3 mg TAE/ $\mathrm{g})$, ethyl acetate leaf extract (25.3 $\mathrm{mg} \mathrm{TAE} / \mathrm{g}$ ) and $22.9 \mathrm{mg} \mathrm{TAE} / \mathrm{g}$ in methanol extract of seed. Among the four plant parts tested, lowest tannin content was obtained in fruit pulp extracts (Table 3). The results of quantitative phytochemical analysis revealed that the presence of greater amounts of phytoconstituents such as phenol, flavonoids and tannins in the methanol extracts leaf, bark, fruit pulp and seed of S. caryophyllatum when compared to other solvent extracts.

Table 2 The quantitative estimation of total flavonoid content of the different solvent extracts of S. caryophyllatum leaf, bark fruit pulp and seed

\begin{tabular}{lllll}
\hline $\begin{array}{l}\text { Phytoconstituents } \\
\text { (mg/g dry weight) }\end{array}$ & Leaf & Bark & Fruit pulp & Seed \\
\hline Hexane & $0.77 \pm 0.03$ & $0.82 \pm 0.02$ & $1.86 \pm 0.03$ & $2.03 \pm 0.02$ \\
Ethyl Acetate & $1.91 \pm 0.01$ & $0.51 \pm 0.01$ & $2.37 \pm 0.03$ & $2.87 \pm 0.1$ \\
Methanol & $5.63 \pm 0.08$ & $3.6 \pm 0.06$ & $2.5 \pm 0.1$ & $2.95 \pm 0.32$ \\
Water & $3.75 \pm 0.06$ & $3.3 \pm 0.05$ & $2.2 \pm 0.02$ & $2.4 \pm 0.02$ \\
\hline
\end{tabular}

Values are given as mean \pm SD of triplicate experiment
Table 3 The quantitative estimation of total tannin content of the different solvent extracts of S. caryophyllatum leaf, bark fruit pulp and seed

\begin{tabular}{lllll}
\hline $\begin{array}{l}\text { Phytoconstituents } \\
\text { (mg/g dry weight) }\end{array}$ & Leaf & Bark & Fruit pulp & Seed \\
\hline Hexane & $15.2 \pm 0.5$ & $10.8 \pm 0.1$ & - & $3.6 \pm 0.1$ \\
Ethyl Acetate & $25.3 \pm 0.8$ & $16.3 \pm 0.03$ & $0.21 \pm 0.08$ & $14.1 \pm 0.1$ \\
Methanol & $36.6 \pm 0.01$ & $31.3 \pm 0.05$ & $0.84 \pm 0.05$ & $22.9 \pm 0.1$ \\
Water & $26.3 \pm 0.1$ & $16.5 \pm 0.1$ & $1.04 \pm 0.1$ & $5.1 \pm 0.1$ \\
\hline
\end{tabular}

Values are given as mean \pm SD of triplicate experiment

\section{Antibacterial sensitivity test}

The antibacterial activity of crude methanol extracts of bark, leaves, fruit pulp and seed was determined by disc diffusion and minimum inhibitory concentration methods against six bacterial species viz. Bacillus cereus, B. licheniformis, Staphyllococcus aureus, S. hominis, Aerococcus viridians and Escherichia coli. Methanol bark extract exhibited the pronounced antibacterial activity against S. hominis, B. licheniformis and $A$. viridian with zone diameter of $12.3 \mathrm{~mm}, 12 \mathrm{~mm}$ and $11.3 \mathrm{~mm}$ respectively. Leaf extract showed potent antibacterial activity against $E$. coli $(14.3 \mathrm{~mm})$, B. cereus $(14 \mathrm{~mm}), S$. aureus $(12.3 \mathrm{~mm})$ but it did not exhibited any zone of inhibition against $S$. hominis. Methanol seed extract exhibited the pronounced antibacterial activity against $A$. viridian, $B$. cereus and $S$. aureus with zone diameter of $12 \mathrm{~mm}, 13 \mathrm{~mm}$ and $10 \mathrm{~mm}$ respectively (Table 4). However, fruit pulp extract exhibited moderate effect of antibacterial activity against some of the tested bacterial strains. The maximum zone of inhibition showed against $S$. aureus with zone diameter of $9 \mathrm{~mm}$. The blind control (DMSO) did not inhibit any of the bacteria tested. The MIC values confirmed the significant activity against the tested microorganisms, as shown in Table 5.

\section{Larvicidal activity}

Results obtained in the present investigation on the leaf essential oil and methanol crude extracts of bark, leaf, fruit pulp and seed of $S$. caryophyllatum exhibited potent larvicidal activity in terms of $\mathrm{LD}_{50}$ and $\mathrm{LD}_{90}$ against the two selected mosquito vectors Aedes aegypti and Culex quinquefasciatus are presented in Table 7. The leaf essential oil of S. caryophyllatum showed 100\% mortality against fourth instar larvae of Ae. aegypti and $C x$. Quinquefasciatus at concentration of $400 \mathrm{ppm}$. At 200 ppm, over 95\% mortality of fourth instar larvae of Ae. aegypti and $81 \%$ mortality of Cx. Quinquefasciatus were observed. The $\mathrm{LD}_{50}$ values of the leaf essential oil recorded after $24 \mathrm{~h}$ of exposure were $54.8 \mathrm{ppm}$ and 95.26 ppm against Ae. aegypti and Cx. quinquefasciatus respectively. The larvicidal activity increased with an increase in the leaf essential oil concentration. Similar trends were observed in the methanol crude extracts of 
Table 4 Antibacterial activities of leaf, bark, fruit pulp and seed methanol extracts of S. caryophyllatum

\begin{tabular}{|c|c|c|c|c|c|c|}
\hline Bacterial strains & Leaf & Bark & Fruit pulp & Seed & Gentamycin & Amp/Sulb \\
\hline S. aureus & $12.3 \pm 0.5$ & $8.3 \pm 0.5$ & $9 \pm 0.57$ & $10 \pm 0.76$ & $21 \pm 1.1$ & $13.5 \pm 1.5$ \\
\hline S.hominis & nd & 12.30 .5 & nd & nd & $28 \pm 0.5$ & $30 \pm 0.5$ \\
\hline A. viridans & $6.3 \pm 0.57$ & $11.3 \pm 0.5$ & $6.8 \pm 0.28$ & $12 \pm 0.57$ & $24.5 \pm 0.5$ & $10 \pm 1.5$ \\
\hline E. coli & $14.3 \pm 0.5$ & $8.3 \pm 0.5$ & $9.83 \pm 0.2$ & $7.5 \pm 0.5$ & $25 \pm 0.5$ & $10 \pm 2.0$ \\
\hline B. cereus & $14 \pm 1.0$ & $8.4 \pm 0.5$ & $8.6 \pm 0.57$ & $13 \pm 1.15$ & $27 \pm 1.1$ & $9.5 \pm 1.1$ \\
\hline B. licheniformis & $11.1 \pm 0.5$ & $12.1 \pm 0.7$ & $7 \pm 0.57$ & $8 \pm 1.1$ & $23 \pm 1.0$ & $31 \pm 1.1$ \\
\hline
\end{tabular}

Values are given as mean \pm SD of triplicate experiment

Diameter of inhibition zones $(\mathrm{mm})$ including disc size $6 \mathrm{~mm}$

Standard antibiotics: Ampicillin/Sulbactum (10/10 mcg/disc); Gentamycin (120 mcg/disc)

nd not detected

bark, leaf, fruit pulp and seed; and the results of mean percentage mortality against two selected mosquito vectors in different concentrations were also shown in Table 6. The methanol extracts of all plant parts exhibited lethal effects on Ae. aegypti and Cx. quinquefasciatus after $24 \mathrm{~h}$ of exposure at different concentrations. The highest mortality rate was found to be in methanol extract of leaf compared with other plant parts. The methanol extracts of leaf, bark and seed extracts showed over $80 \%$ mortality at $500 \mathrm{mgL}$. Leaf methanol extract of $S$. caryophyllatum was effective against the fourth instar larvae of Ae. aegypti and $C x$. quinquefasciatus with $\mathrm{LD}_{50}$ values of $80.4\left(\mathrm{LD}_{90}=346.5 \mathrm{mg} / \mathrm{L}\right)$ and $128.1 \mathrm{mg} / \mathrm{L}$ $\left(\mathrm{LD}_{90}=363.9 \mathrm{mg} / \mathrm{L}\right)$ respectively. The bark and seed methanol extracts had significant larvicidal effect with $\mathrm{LD}_{50}$ and $\mathrm{LD}_{90}$ values found to be $303.6\left(\mathrm{LD}_{90}=\right.$ $541.3 \mathrm{mg} / \mathrm{L})$ and $286.0\left(\mathrm{LD}_{90}=554.8 \mathrm{mg} / \mathrm{L}\right)$ against $A e$. aegypti and $286.4\left(\mathrm{LD}_{90}=509.5 \mathrm{mg} / \mathrm{L}\right)$ and $300.2\left(\mathrm{LD}_{90}\right.$ $=547.2 \mathrm{mg} / \mathrm{L}$ ) against $C x$. quinquefasciatus. Methanol fruit pulp showed the least larvicidal activity compared with other three plant parts studied. At $500 \mathrm{mg} / \mathrm{l}$ concentration, it caused $71.6 \%$ and $48.3 \%$ larval mortality against Ae.aegypti and $C x$. quinquefasciatus with $\mathrm{LD}_{50}$ and $\mathrm{LD}_{90}$ values of $387.0\left(\mathrm{LD}_{90}=651.6 \mathrm{mg} / \mathrm{L}\right)$ and $519 \mathrm{mg} / \mathrm{l}\left(\mathrm{LD}_{90}=876.1 \mathrm{mg} / \mathrm{L}\right)$ respectively. The $\mathrm{LD}_{50}$ and its lower, upper confident levels, along with the regression analyses are given in Table 7 . The results obtained in this study clearly proved that the $S$.

Table 5 Minimum inhibitory concentration (MIC) of leaf, bark, fruit pulp and seed methanol extracts against pathogenic bacteria

\begin{tabular}{lllll}
\hline Bacterial strains & MIC leaf & MIC bark & MIC Fruit & MIC Seed \\
\hline S. aureus & 500 & 1000 & 500 & 500 \\
S.hominis & nd & 500 & nd & nd \\
A. viridans & nd & 500 & 1000 & 250 \\
E. coli & 100 & 1000 & 500 & 1000 \\
B. cereus & 100 & 1000 & 500 & 250 \\
B. licheniformis & 500 & 500 & 1000 & 1000 \\
\hline
\end{tabular}

nd not detected; MIC values are given in $\mu \mathrm{g} / \mathrm{ml}$ concentration caryophyllatum leaf essential oil and effective constituents of methanol extract of different plant parts could be considered as a potent source for the production of ecofriendly larvicidal agent against the disease causing common mosquito vectors.

\section{Free radical scavenging assays}

DPPH is a stable free radical, which has been widely accepted as a tool for estimating free radical-scavenging

Table 6 Larvicidal activity indifferent concentrations of S. caryophyllatum plant extracts and essential oil against $A$ e. aegypti and Cx. quinquefasciatus ( $\mathrm{mg} / \mathrm{l}$ )

\begin{tabular}{|c|c|c|c|}
\hline $\begin{array}{l}\text { Plant parts } \\
\text { used }\end{array}$ & $\begin{array}{l}\text { Concentrations } \\
(\mathrm{mg} / \mathrm{l})\end{array}$ & $\begin{array}{l}24 \text { h \% Mortality } \\
\text { (Ae. aegypti) }\end{array}$ & $\begin{array}{l}24 \mathrm{~h} \% \text { Mortality } \\
\text { (CX. Quinquefasciatus) }\end{array}$ \\
\hline & 500 & $83.3 \pm 2$ & $86.6 \pm 5.7$ \\
\hline \multirow[t]{4}{*}{ Bark } & 250 & $56.7 \pm 2.8$ & $57 \pm 3$ \\
\hline & 125 & $15 \pm 0.0$ & $18.3 \pm 2.8$ \\
\hline & 62.5 & 0 & $6.6 \pm 2.8$ \\
\hline & 500 & $98.3 \pm 2.8$ & $96.6 \pm 2.9$ \\
\hline \multirow[t]{4}{*}{ Leaf } & 250 & $91.7 \pm 5.7$ & $85 \pm 5$ \\
\hline & 125 & $68.3 \pm 7.6$ & $55 \pm 5$ \\
\hline & 62.5 & $35 \pm 5$ & $26.6 \pm 2.8$ \\
\hline & 500 & $71.6 \pm 3$ & $48.3 \pm 7.6$ \\
\hline \multirow[t]{4}{*}{ Fruit pulp } & 250 & $28.3 \pm 5.7$ & $21.6 \pm 3$ \\
\hline & 125 & $16.6 \pm 2.8$ & $11.6 \pm 2.8$ \\
\hline & 62.5 & 0 & 0 \\
\hline & 500 & $81.6 \pm 3$ & $81.7 \pm 2.8$ \\
\hline \multirow[t]{5}{*}{ Seed } & 250 & $55 \pm 5$ & $56.6 \pm 3$ \\
\hline & 125 & $26.6 \pm 2.8$ & $15.0 \pm 0.0$ \\
\hline & 62.5 & 0 & $6.6 \pm 3$ \\
\hline & 400 & $100 \pm 0.0$ & $100 \pm 0.0$ \\
\hline & 200 & $95 \pm 5.0$ & $81.6 \pm 2.8$ \\
\hline \multirow{3}{*}{$\begin{array}{l}\text { Essential oil } \\
\text { (ppm) }\end{array}$} & 100 & $88.3 \pm 2.8$ & $71.6 \pm 3$ \\
\hline & 50 & $51.6 \pm 3$ & $36.7 \pm 2.8$ \\
\hline & 10 & $18.3 \pm 2.8$ & $8.3 \pm 2$ \\
\hline
\end{tabular}

Values are given as mean \pm SD of triplicate experiment 
Table 7 LD50 and other statistical analysis of S. caryophyllatum plant extracts and essential oil against fourth instar larvae of Ae. aegypti and $C x$. quinquefasciatus

\begin{tabular}{|c|c|c|c|c|c|}
\hline Parts used & Species & $\mathrm{LD}_{50}(\mathrm{ppm})$ & UCL-LCL & $x^{2}(d f=2)$ & $p$-level \\
\hline \multirow[t]{2}{*}{ Bark } & A. aegypti & $303.6 \pm 33.8$ & $235.9-371$ & 0.2508 & 0.8821 \\
\hline & Cx. Quinquefasciatus & $286.4 \pm 31.7$ & $222.8-350$ & 0.3433 & 0.8423 \\
\hline \multirow[t]{2}{*}{ Leaf } & A. Aegypti & $80.4 \pm 37.9$ & $4.52-156.7$ & 0.0402 & 0.9801 \\
\hline & Cx. Quinquefasciatus & $128.1 \pm 33.5$ & $60.87-195.3$ & 0.0162 & 0.9919 \\
\hline \multirow[t]{2}{*}{ Fruit pulp } & A. Aegypti & $387.3 \pm 37$ & $312-462$ & 1.1505 & 0.5626 \\
\hline & Cx. Quinquefasciatus & $519 \pm 50.7$ & $418-621$ & 0.3212 & 0.8516 \\
\hline \multirow[t]{2}{*}{ Seed } & A. Aegypti & $286 \pm 38.2$ & $209-362.8$ & 0.7243 & 0.6962 \\
\hline & Cx. Quinquefasciatus & $300.2 \pm 35$ & $229-370$ & 0.3229 & 0.8509 \\
\hline \multirow[t]{2}{*}{ Es. Oil } & A. Aegypti & $54.84 \pm 20.5$ & $13.64-96.05$ & 0.7145 & 0.8698 \\
\hline & Cx. Quinquefasciatus & $95.26 \pm 21.2$ & $52.87-137.6$ & 0.4343 & 0.9331 \\
\hline
\end{tabular}

Values are given as mean $\pm \mathrm{SE}$ of triplicate experiment

activities of antioxidants. The percentage inhibition of DPPH and ABTS in the methanol extracts of bark, leaves, fruit pulp and seeds at different concentrations are shown in Figs. 1 and 2. The method is based on the reduction of methanolic-DPPH solution because of the presence of antioxidant substances having hydrogen donating groups $(\mathrm{RH})$ such as phenolics and flavonoids compounds due to the formation of non radical DPPH$\mathrm{H}$ form. Free radical scavenging activity indicated that methanol bark, leaves, fruit and seeds extracts have significant free radical scavenging ability on DPPH with percentage inhibition of $88.15 \%, 81.31 \%, 75.24 \%$ and $83.36 \%$ respectively. The four extracts also revealed scavenging effects on ABTS with percentage inhibition of $88.15 \%, 81.31 \%, 75.24 \%$ and $83.36 \%$ respectively. The $\mathrm{IC}_{50}$ values of $\mathrm{DPPH}$ and ABTS radical activities of the methanol extracts of bark, leaves, fruit pulp, seeds and positive controls were shown in Table 8 . A lower $\mathrm{IC}_{50}$ value indicates higher antioxidant activity. The results revealed that free radical scavenging activity of methanol fruit and leaves extracts has less radical scavenging ability on $\mathrm{DPPH}$ with $\mathrm{IC}_{50}$ value of $69.41 \mu \mathrm{g} / \mathrm{mL}$, while the bark and seeds methanol extracts showed IC50 value of $48.37 \mu \mathrm{g} / \mathrm{mL}$ compared to the positive control ascorbic acid $\left(\mathrm{IC}_{50}=9.55 \mu \mathrm{g} / \mathrm{mL}\right)$ and gallic acid $\left(\mathrm{IC}_{50}=7.05 \mu \mathrm{g} /\right.$ $\mathrm{mL})$. The ABTS radical activities of the methanol extracts of bark, leaves, fruit pulp and seed showed $\mathrm{IC}_{50}$ values of $10.26 \mu \mathrm{g} / \mathrm{mL}, 13.2 \mu \mathrm{g} / \mathrm{mL}, 69.4 \mu \mathrm{g} / \mathrm{mL}$ and $20.1 \mu \mathrm{g} / \mathrm{mL}$ respectively. The positive control ascorbic acid and gallic acid showed the $\mathrm{IC}_{50}$ values of $5.6 \mu \mathrm{g} / \mathrm{mL}$ and $4.9 \mu \mathrm{g} / \mathrm{mL}$ respectively.

\section{In vitro a-amylase and a-glucosidase assays}

The in vitro $\alpha$-amylase and $\alpha$-glucosidase inhibitory studies of the methanol crude extracts of four different plant parts of S. caryophyllatum (Bark, leaf fruit pulp and seed) showed good inhibitory activities in concentration dependent manner. Percentage inhibition was tested with different concentrations of four methanol extracts $100-500 \mu \mathrm{g} / \mathrm{ml}$ for $\alpha$-amylase and $20-100 \mu \mathrm{g} / \mathrm{ml}$ for $\alpha$-glucosidase. The bark extract indicated a potent inhibitory activity of $\alpha$-amylase followed by seed, leaf and fruit extracts. The maximum percentage inhibitory activity of $78.03 \%$ was showed at concentration of $500 \mu \mathrm{g} / \mathrm{ml}$ seed extracts followed by bark (78.03\%), leaf (69.4\%) and fruit pulp (56.9\%) at the same concentration. While the percentage inhibitory activity of four extracts also showed potent inhibition of $\alpha$-glucosidase. The results showed that maximum inhibition exhibited at the concentration of $100 \mu \mathrm{g} / \mathrm{ml}$ by bark extract (80.9\%) compared with other extracts, leaf (78.2\%), seed (77.59\%) and fruit pulp (63.35\%). The percentage inhibition and IC50 values obtained in the analyses were shown in Fig. 3a, b and Table 8.

\section{Discussion}

Phytochemical screening provides fundamental information about the medicinal importance of the plant extracts. Phenolic compounds play an important role in plant defence mechanisms against invading bacteria and other types of environmental stress, such as wounding and excessive light or ultraviolet radiation [31, 32]. These compounds can act as antioxidants by chelating metal ions, preventing radical formation and improving the antioxidant endogenous system [33]. Antioxidants which predominantly originate from phytochemicals have been reported to play an important role in the treatment of diabetes [34]. Our results also in accordance with previous report that showed high phenol content in $S$. aqueum leaf ethanol extracts may be the reason for its high anti-glycation activity [35]. 

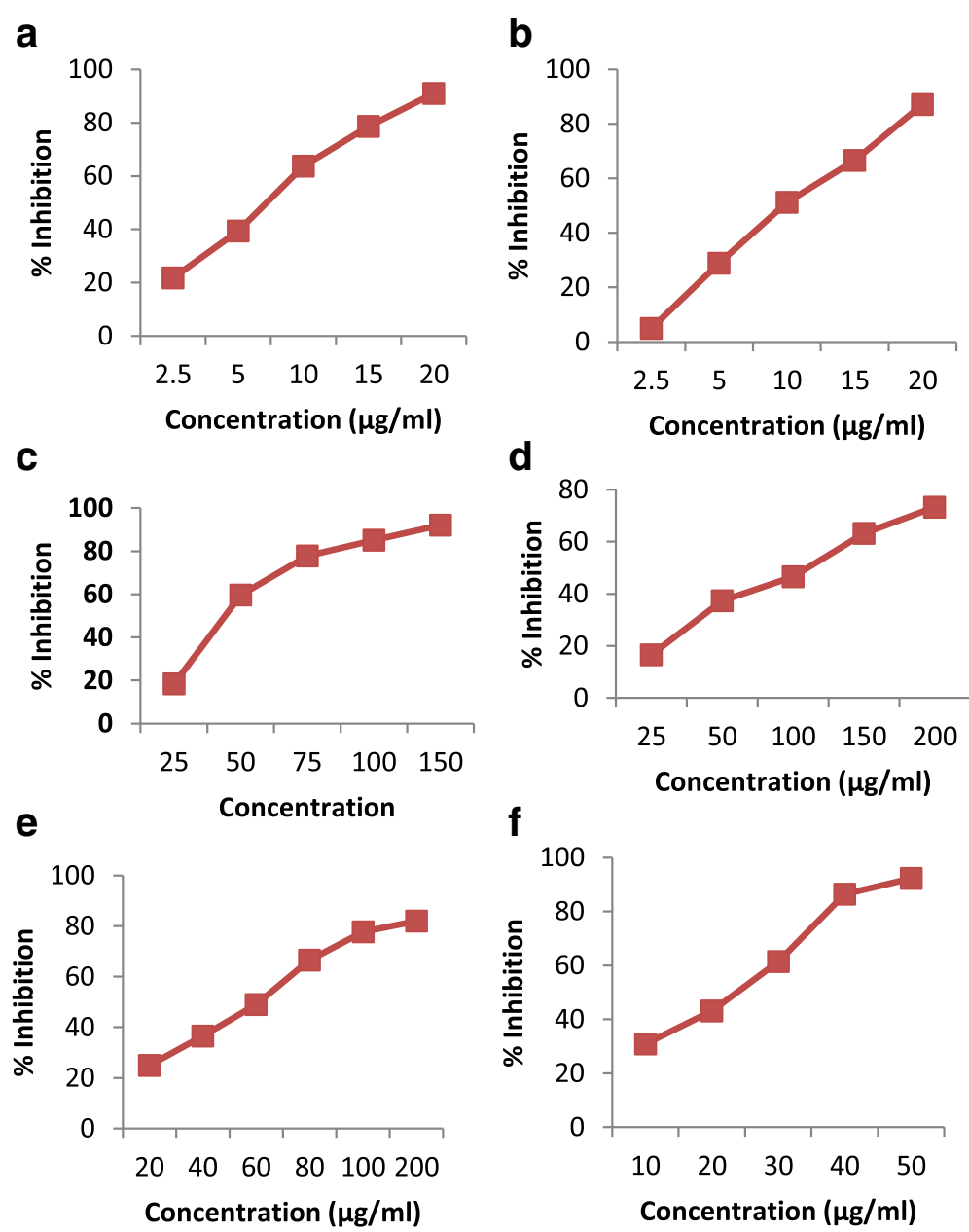

Fig. 1 DPPH free radical scavenging activity of S.caryophyllatum a Ascorbic acid; b Gallic acid; c Bark methanol; d Leaf methanol; e Fruit pulp methanol; $\mathbf{f}$ Seed methanol

Syzygium species are known to be very rich in flavonoids, tannins and other polyphenol derivatives [36-39]. Flavonoids, tannins, anthocyanins and other phenolic constituents present in bark, leaves and fruits are potential antioxidants. Flavonoids are known to regenerate the damaged pancreatic $\beta$-cells in the alloxan induced diabetic rats [40]. Tannins are considered nutritionally undesirable because they precipitate proteins, inhibit digestive enzymes and affect the absorption of minerals and vitamins. Tannins were reported to exhibit antiviral, antibacterial and anti-tumour activities. However, some kinds of tannins can reduce the mutagenicity of a number of mutagens and also exhibited antioxidant, anticarcinogenic and antimicrobial activities [41].

Food rich in antioxidants plays a crucial role in the prevention of various types of cancers, cardiovascular and Alzheimer's diseases [42]. Antioxidants which predominantly originate from phytochemicals like flavonoids and phenols have been reported to play an important role in the treatment of diabetes [34] (Kim et al., 2011). Total antioxidant capacity may better reflect the health beneficial quality of foods than individual measurements due to the possible cooperative action of antioxidants [43]. Seeds of S. cumini one of the close related species of S.caryophyllatum have been reported to be rich in flavonoids, which account for the scavenging of free radicals and a protective effect on antioxidant enzymes and they have also been found to have high total phenolic content with significant antioxidant activity $[44,45]$. The results obtained in present study are in agreement with previous studies which showed that high total phenolic content increases the antioxidant activity [46]. According to previous reports the close related species S. cumini, S. aromaticum fruits and leaves extract have been reported to have high antioxidant activity $[47,48]$.

Different parts of $S$. cumini such as seeds, bark, fruit and leaves have been used in traditional medicine as a 

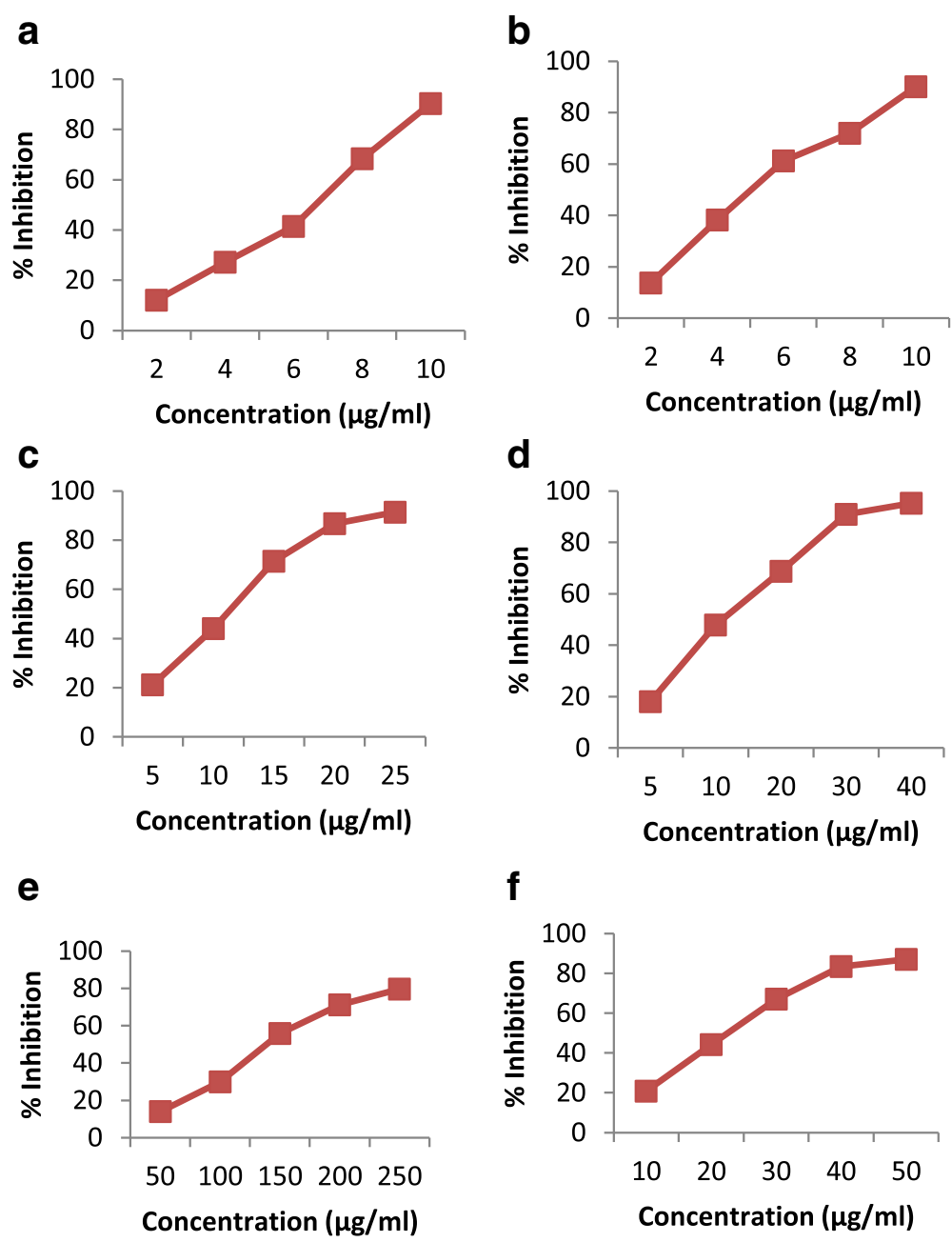

Fig. 2 ABTS free radical scavenging activity of S.caryophyllatum a Ascorbic acid; b Gallic acid; c Bark methanol; d Leaf methanol; e Fruit pulp methanol; $\mathbf{f}$ Seed methanol

Table 8 Free radical scavenging activities of S. caryophyllatum bark, leaf, fruit pulp, seed methanol extracts and standard antioxidants (Ascorbic acid and Gallic acid)

\begin{tabular}{lllll}
\hline \multirow{2}{*}{ Samples } & \multicolumn{4}{l}{$\mid \mathrm{IC} 50(\mu \mathrm{g} / \mathrm{ml})$} \\
\cline { 2 - 5 } & DPPH & ABTS & a -amylase & a -glucosidase \\
\hline Bark & $19.07 \pm 0.2$ & $10.26 \pm 0.06$ & $191 \pm 3.2$ & $53.75 \pm 1.6$ \\
Leaf & $34.9 \pm 1.2$ & $13.2 \pm 0.03$ & $265.4 \pm 5.7$ & $57.8 \pm 0.3$ \\
Fruit pulp & $69.4 \pm 0.7$ & $120.2 \pm 0.4$ & $291.5 \pm 4.3$ & $61.8 \pm 0.1$ \\
Seed & $41.68 \pm 0.6$ & $20.1 \pm 0.14$ & $265 \pm 1.8$ & $56.1 \pm 0.2$ \\
Ascorbic acid & $9.55 \pm 0.01$ & $5.6 \pm 0.03$ & - & - \\
Gallic acid & $7.05 \pm 0.09$ & $4.9 \pm 0.05$ & - & - \\
Acarbose & - & - & $194.2 \pm 5.1$ & $41.13 \pm 0.4$ \\
\hline
\end{tabular}

Each values in the table was obtained by calculating the average of three analysis \pm SE remedy for diabetes mellitus in many countries $[49,50]$. The use of alpha-amylase and alpha-glucosidase enzyme inhibitors could be a prospective therapeutic agent for the effective management of postprandial hyperglycemia in diabetes mellitus patients [51]. It is obvious that flavonoids and polyphenols have been shown to inhibit pancreatic alpha-amylase and intestinal alpha-glucosidase enzymes and also reported that there is a positive correlation between the inhibition of alpha-amylse and alphaglucosidase and flavonoids and polyphenol content [5254]. Our investigation of in vitro studies of bark, leaf, fruit pulp and seed methanol extracts of S. caryophyllatum also showed remarkable inhibition of alpha-amylase and alpha-glucosidase suggesting the presence of potential enzyme inhibiting compounds in the plant extracts.

The use of plant extract for mosquito control save the environment from synthetic chemicals. Plant products are emerging as a potential source of mosquito control 

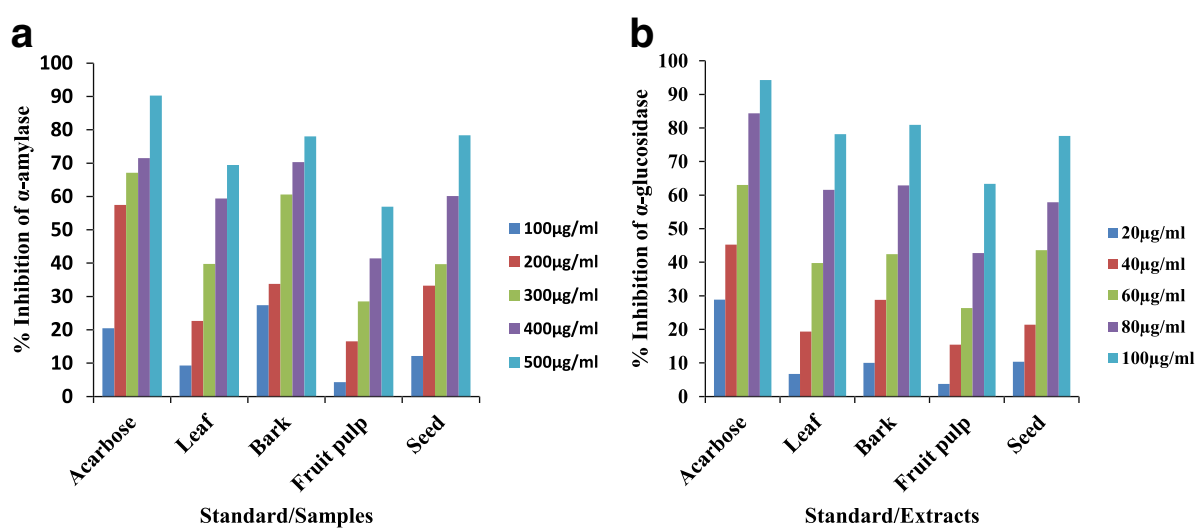

Fig. $\mathbf{3}$ a In vitro alpha amylase activity of S. caryophyllatum. $\mathbf{b}$ In vitro alpha-glucosidase activity of S. caryophyllatum

and among them essential oil have special interest due to their insecticidal properties $[55,56]$. In general essential oils from plant sources have been considered important natural resources to act as insecticides [57, 58]. Essential oils derived from various plants not only exhibit inhibitory activity against fungi, bacteria and dermites but also show strong mosquito larvicidal and repellent activities [59]. The finding of the present study compare well with previous finding of Bagavan and Rahuman [60] who reported that the hexane crude extract of S. aromaticum flower bud exhibited potent larvicidal activity against fourth instar of Anopheles vagus and $C x$. vishnui. A similar study conducted by Fayemiwo et al. [61] reported that the flower bud oil of S. aromaticum was effective against the Ae. aegypti $\left(\mathrm{LC}_{50}=\right.$ $92.56 \mathrm{mg} / \mathrm{l})$ and $C x$. quinquefasciatus $\left(\mathrm{LC}_{50}=124.4 \mathrm{mg} /\right.$ l) larvae. Our results are also comparable to earlier reports of Kaushik and Saini [62] who observed that the highest mortality was found in methanol leaf extract of S. cumini against the larvae of Ae. aegypti. The results of the present study suggested that the larvicidal potential of leaf essential oil and plant extracts of S. caryophyllatum and emphasize need to incorporate them in vector control and management programmes.

\section{Conclusion}

Based on the results of bioprospecting and biological screening of S. caryophyllatum proved to be a good medicinal plant used for curing various ailments in different traditional systems of medicine. The results of bioprospecting investigation the various polyphenolic compounds present in the plant extracts attribute the antioxidant, alpha amylase, alpha glucosidase, antibacterial and larvicidal activities. Thus the present study suggests that S.caryophyllatum bark, leaf, fruit pulp and seed can be used as natural antioxidant source to prevent diseases associated with free radicals. Also, this plant can be a good source for further purification studies for isolation and characterization of compounds related to these antioxidants, antidiabetic and antibacterial activities. These findings justify and confirm the traditional uses of this plant. Further research is necessary in order to know all the active principles and their pharmacological properties.

\section{Abbreviations \\ ABTS: -2,2'-azino-bis(3-ethylbenzothiazoline-6-sulphonic acid); DMSO: Dimethyl sulfoxide; DPPH: 1,1-diphenyl-2-picrylhydrazyl; GAE: Gallic acid equivalent; $I_{50}$ : 50\% Inhibitory concentration; $L_{50}$ : 50\% Lethal Dose; MHA: Mueller-Hinton agar medium; mM: Milli molar; $\mathrm{Na}_{2} \mathrm{CO}_{3}$ : Sodium \\ Carbonate; NaCl: Sodium Chloride; PNPG: $p$-nitrophenyl-a-D-glucopyranoside; RE: Rutin equivalent; TAE: Tannic acid equivalent}

\section{Acknowledgments}

The authors would like to express their gratitude to Centre for Research in Medical Entomology (CRME), Madurai, India for providing mosquitos eggs for larvicidal analysis.

\section{Funding}

First author thanks University Grant Commission for the award of meritorious fellowship. Corresponding author thanks partial financial support through University Grant Commission-Centre of Advanced Study (UGC-CAS), Department of Biotechnology- Interdisciplinary Programme of Life Sciences for Advanced Research (DBT-IPLS) and Department of Science and Technology (DST)-Purse programmes.

Availability of data and materials Not Applicable.

Authors' contributions

Both the authors are equally contributed. Both the authors read and approved the final manuscript.

\section{Authors' information}

Dr. Stalin: Completed his PhD in Department of Plant Science, School of Biological Sciences, Madurai Kamaraj University, Madurai. His area of research is species distribution modelling, bioprospecting and conversation of selected medicinal plant through phenological studies and in vitro propagation.

Dr. P. Sudhakar Swamy: Professor, Department of Plant Science, School of Biological Sciences, Madurai Kamaraj University, Madurai. His area of specialisation is Forest ecology, invasion ecology, bioprospecting of medicinal plants and their conservation.

Ethics approval and consent to participate Not Applicable. 


\section{Consent for publication}

Not Applicable.

\section{Competing interests}

The authors declare that they have no competing interests.

\section{Publisher's Note}

Springer Nature remains neutral with regard to jurisdictional claims in published maps and institutional affiliations.

Received: 30 October 2017 Accepted: 27 December 2017 Published online: 18 January 2018

\section{References}

1. Gupta SK. Pharmacology and therapeutics in the new millennium. New Delhi: Narosa Publishing House; 2001.

2. Wong $\mathrm{C}$, Li H, Cheng K, Chen F, et al. A systematic survey of antioxidant activity of 30 Chinese medicinal plants using the ferric reducing antioxidant power assay. Food Chem. 2006;97:705-11.

3. Ames SN, Shigrenaga MK, Hagen TM, et al. Oxidants, antioxidant and the degenerative diseases of aging. Proc Natl Acad Sci U S A. 1993; 90:7915-22.

4. Shukla VKS, Wanasundara PKJPD, Shahidi F, et al. Natural antioxidants from oilseeds. In: Shahidi F, editor. Natural antioxidants: chemistry, health effects, and applications. Champaign: AOCS Press; 1997. p. 97-132.

5. Mohamed AA, Khalil AA, El-Beltagi HES, et al. Antioxidant and antimicrobial properties of kaff maryam (Anastatica hierochuntica) and doum palm (Hyphaene thebaica). Grasas Y Aceites. 2010;61:67-75.

6. Ozsoy N, Can A, Yanardag R, Akev A, et al. Antioxidant activity of Smilax excelsa leaf extracts. Food Chem. 2010;X110:571-83.

7. Giovanelli G, Buratti S. Comparison of polyphenolic composition and antioxidant activity of wild Italian blueberries and some cultivated varieties. Food Chem. 2009;112:903-8.

8. Salah N, Miller NJ, Paganga G, Tijburg L, Bolwell GP, et al. Polyphenolic flavanols as scavengers of aqueous phase radicals and as chain breaking antioxidants. Arch Biochem Biophys. 1995;322:339-46.

9. Oomah BD, Cardador-Martinez A, Loarca-Pina G, et al. Phenolics and antioxidative activities in common beans. J Sci Food Agric. 1995; 85:935-42.

10. Brighente $I M C$, Dias $M$, Verdi LG, Pizzolatti MG. Antioxidant activity and total phenolic content of some Brazilian species. Pharm. Biol. 2007:45:156-61.

11. Salazar R, Pozes ME, Cordero P, Perez J, Salinas MC, Waksman N. Determination of the antioxidant activity of plants from Northeast Mexico. Pharm Biol. 2008;46:166-70.

12. Ahmad I, Aqil F. Vitro efficacy of bioactive extracts of 15 medicinal plants against SbL-producing multidrugresistant enteric bacteria. Microbiol Res. 2007;162:264-75

13. Barbour EK, Al Sharif M, Sagherian VK, Habre AN, Talhouk RS, Talhouk SN. Screening of selected indigenous plants of Lebanon for antimicrobial activity. J Ethnopharmacol. 2004;93:1-7.

14. Iwu MW, Duncan AR, Okunji CO. New antimicrobials of plant origin. In: Janick J, editor. Perspectives on new Crops and new Uses. Alexandria: ASHS Press; 1999. p. 457-62.

15. WHO (2013). World Filariasis Report. Geneva: Switzerland; 282

16. WHO (2015). Dengue and Severe Dengue Fact Sheet. World Malaria Report. Washington, DC: National Press Club; 1-5.

17. Ediriweera ERHSS, Ratnasooriya WDA. Review on herbs used in treatment of diabetes mellitus by Sri Lankan and traditional physicians. Ayu. 2009;30:373-91.

18. Shilpa KJ, Krishnakumar G. Phytochemical screening, antibacterial and antioxidant efficacy of the leaf and bark extracts of Syzygium caryophyllatum (L.) Alston. Int J Pharm Pharm Sci. 2012;4:198-202.

19. Rabeque CS, Padmavathy S. Comparative phytochemical analysis of root extracts of S. caryophyllatum (L.) Alston and S. densiflorum wall. Pharmacie Globale (IJCP). 2014;04:1-3.

20. Harsha VH, Sripathy V, Hedge GK. Ethnoveterinary practices in Uttara Kannada district of Karnataka. Indian J Tradit Knowl. 2005;4:253-8.

21. Ratheesh Narayanan MK, Anilkumar N, Balakrishnan V, Sivadasan M, Ahmed Alfarhan $\mathrm{H}$, Alatar AA. Wild edible plants used by the
Kattunaikka, Paniya and Kuruma tribes of Wayanad District, Kerala, India. J Med Plant Res. 2011;5:3520-9.

22. Lister B, Wilson P. Measurement of total phenolics and ABTS assay for antioxidant activity (personal communication). Crop Research Institute: Lincoln; 2001

23. Quettier DC, Gressier B, Vasseur J, Dine T, Brunet C, Luyckx MC, Cayin JC, Bailleul F, Trotin F. Phenolic compounds and antioxidant activities of buckwheat (Fagopyrum esculentum Moench) hulls and flour. J Ethnopharmacol. 2000;72:35-42.

24. Shanmugam T, Sathish Kumar T, Panneer Selvam K. Laboratory handbook on biochemistry. New Delhi: PHI Learning Pvt. Ltd.; 2010.

25. Shimada K, Fujikawa K, Yahara K, Nakamura T. Antioxidative properties of xanthan on the autoxidation of soybean oil in cyclodextrin emulsion. J Agric Food Chem. 1992;40:945-8.

26. Re R, Pellegrini N, Proteggente A, Pannala A, Yang M, Rice-Evans C. Antioxidant activity applying an improved ABTS radical cation decolourization assay. Free Radic Biol Med. 1999:26:1231-7.

27. Ranilla LG, Kwon YI, Genoves MI, Lajolo FM, Shetty K. Antidiabetes and antihypertension potential of commonly consumed carbohydrate sweeteners using in vitro models. J Med Food. 2008;11(2):337-48.

28. Dong HQ, Li M, Zhu F, Liu FL, Huang JB. Inhibitory potential of trilobatin from Lithocarpus polystachyus Rehd against a- glucosidase and a-amylase linked to type 2 diabetes. Food Chem. 2012;130:261-6.

29. Irobi ON, Moo-Young M, Anderson WA, Daramola SO. Antimicrobial activity of the bark of Bridelia ferruginea (Euphorbiaceae). Int J Pharmacog. 1994;34:87-90.

30. World Health Organization. Report of the WHO informal consultation on the evaluation on the testing of insecticides, CTD/WHO PES/IC/96.1. Geneva: WHO; 1996. p. 69.

31. Harbourne JB. The flavonoids: advances in research since 1986. London: Chapman \& Hall; 1994.

32. Wallace G, Fry SC. Phenolic components of the plant cell wall. Int Rev Cytol. 1994;151:229-67.

33. Al-Azzawie HF, Mohamed-Saiel SA. Hypoglycemic and antioxidant effect of oleuropein in alloxan-diabetic rabbits. Life. Science. 2006;78:1371-7.

34. Kim JS, Hyun TK, Kim MJ. The inhibitory effects of ethanol extracts from Sorghum, foxtail millet and proso millet on a-glycosidase and a-amylase activities. Food Chem. 2011;124:1647-51.

35. Palanisamy UD, Ling LT, Manoharan T, Sivapalan V, Subramaniam T, Helme MH. Standardized extract of Syzygium aqueum: a safe cosmetic ingredient. Int J Cosmet Sci. 2011;1:7.

36. Chattopadhyay D, Sinha BK, Vaid LK. Antibacterial activity of Syzygium species. Fitoterapia. 1998;69:356-67.

37. Mahmoud II, Marzouk MSA, Moharram FA, El-Gindi MR, Hassan AMK. Acylated flavonol glycosides from Eugenia jambolana leaves. Phytochemistry. 2001;58:1239-44.

38. Sharma SB, Nasir A, Prabhu KM, Dev G, Murthy PS. Hypoglycemic and hypolipidemic effect of ethanolic extracts of seeds of $E$. Jambolana in alloxan-induced diabetic model of rabbits. J Ethnopharmacol. 2003;85:201-6.

39. Reynertson KA, Yang H, Jiang B, Basile MJ, Kennelly MEJ. Quantitative analysis of antiradical phenolic constituents from fourteen edible Myrtaceae fruits. Food Chem. 2008;109:883-90.

40. Hakkim FL, Girija S, Kumar RS, Jalaluddeen MD. Effect of aqueous and ethanol extracts of Cassia auriculata L. flowers on diabetes using alloxan induced diabetic rats. Int J diabetes and Metabolism. 2007;15:100-6.

41. Chung KT, Wei C, Johnson MG. Are tannins a double edged sword in biology and health. Trends Food Sci Technol. 1998;9:168-75.

42. Cui $K$, Luo XL, KY X, Murthy MRV. Role of oxidative stress in neurodegeneration: recent developments in assay methods for oxidative stress and nutraceutical antioxidants. Prog NeuroPsychopharmacol Biol Psychiatry. 2004;28:771-99.

43. Ghiselli A, Serafini M, Natella F, Scaccini C. Total antioxidant capacity as a tool to assess redox status: critical view and experimental data. Free Rad Biol Med. 2000;29:1106-14.

44. Ravi K, Ramachandran B, Subramanian S. Protective effect of Eugenia jambolana seed kernel on tissue antioxidants in streptozotocin induced diabetic rats. Biol Pharm Bull. 2004:27:1212-7.

45. Bajpai M, Pande A, Tewari SK, Prakash D. Phenolic contents and antioxidant activity of some food and medicinal plants. Int J Food Sci Nutr. 2005;56:287-29 
46. Abhishek KS, Vinod KV. Syzygium cumini: An overview. J Chem Pharm Res. 2011;3:108-11

47. Ruan ZP, Zhan LL, Lin YM. Evaluation of the antioxidant activity of Syzygium cumini leaves. Molecules. 2008;13:2545-56.

48. Jirovetz L, Buchbauer G, Stoilova I, Stoyanova A, Krastanov A, Schmidt E. Chemical composition and antioxidant properties of clove leaf essential oil. J Agric Food Chem. 2006;54:6303-7.

49. Indira G, Mohan R. Jamun Fruits, National Institute of Nutrition. Hyderabad: Indian Council of Medical Research; 1993. p. 34-7.

50. Teixeira CC, Pinto LP, Kessle FHP, Knijnik L, Pinto CP, Gastaldo GJ, Fuchs FD. The effect of Syzygium cumini (L.) Skeels on post-prandial blood glucose levels in non-diabetic rats and rats with streptozotocin-induced diabetes mellitus. J Ethnopharmacol. 1997;56:209-13.

51. Ali H, Houghton PJ, Soumyanath A. a-amylase inhibitory activity of some Malaysian plants used to treat diabetes; with particular reference to Phyllanthus amarus. J Ethnopharmacol. 2006;107:449-55.

52. Adisakwattana $\mathrm{S}$, Ruengsamran $\mathrm{T}$, Kampa $\mathrm{P}$, Sompong $\mathrm{W}$. In vitro inhibitory effects of plant based foods and their combinations on intestinal a-glucosidase and pancreatic a-amylase. BMC Complement Altern Med. 2012;12:110.

53. Pereira DF, Cazarolli LH, Lavado C, Mengatto V, Figueiredo MS, Guedes A, Pizzolatti MG, Silva FR. Effect of flavonoids on a-glucosidase activity: potential targets for glucose homeostasis. Nutrition. 2011;27:1161-7.

54. Xiao J, Kai G, Ni X, Yang F, Chen X. Interaction of natural polyphenols with a-amylase in vitro: molecular property-affinity relationship aspect. Mol BioSyst. 2011;7:1883-90.

55. Cheng SS, Chang HT, Chang ST, Tsai KH, Chen WJ. Bioactivity of selected plant essential oils against yellow fever mosquitoes Aedes aegypti larvae. Bioresour Technol. 2003;89:99-102.

56. Sukumar K, Perich MJ, Boobar LR. Botanical derivatives in mosquito control: a review. J Am Mosq Control Assoc. 1991;7:210-37.

57. Gbolade AA. Plant-derived insecticides in the control of malaria vector. $J$ Trop Med Plants. 2001;2:91-7.

58. Adebayo TA, Gbolade AA, Olaifa JJ. Comparative study of toxicity of essential oils to larvae of three mosquito species. Nig J Nat Med. 1999:3:74-6.

59. Cheng SS, Liu JY, Tsai KH, Chen WJ, Chang ST. Chemical composition and mosquito larvicidal activity of essential oils form leaves of different Cinnamonum osmophloem provenances. J Agric Food Chem. 2004;52: 4395-400.

60. Bagavan A, Rahuman AA. Evaluation of larvicidal activity of medicinal plant extracts against three mosquito vectors. Asian Pac J Trop Med. 2011:4:29-34.

61. Fayemiwo KA, Adeleke MA, Okoro OP, Awojide SH, Awoniyi IO. Larvicidal efficacies and chemical composition of essential oils of Pinus sylvestris and Syzygium aromaticum against mosquitoes. Asian Pac J Trop Biomed. 2014; 4(1):30-4.

62. Kaushik R, Saini P. Screening of some semi-arid region plants for larvicidal activity against Aedes aegypti mosquitoes. J Vector Borne Dis. 2009;46:244-6.

\section{Submit your manuscript to a SpringerOpen ${ }^{\circ}$ journal and benefit from:}

- Convenient online submission

- Rigorous peer review

- Open access: articles freely available online

- High visibility within the field

- Retaining the copyright to your article

Submit your next manuscript at $\gg$ springeropen.com 